\title{
Transcriptional profiling of Corynebacterium glutamicum metabolism during organic acid production under oxygen deprivation conditions
}

\section{Correspondence \\ Hideaki Yukawa \\ mmg-lab@rite.or.jp}

Received 9 January 2007

Revised 4 March 2007

Accepted 10 April 2007

\author{
Masayuki Inui, Masako Suda, Shohei Okino, Hiroshi Nonaka, \\ László G. Puskás, Alain A. Vertès and Hideaki Yukawa
}

\author{
Research Institute of Innovative Technology for the Earth (RITE), 9-2 Kizugawadai, Kizugawa, \\ Kyoto, 619-0292, Japan
}

\begin{abstract}
A transcriptional profiling of the metabolism of Corynebacterium glutamicum under oxygen deprivation conditions is reported. It was observed that the glucose consumption rate per cell when C. glutamicum cells were incubated under oxygen deprivation conditions was higher than that achieved by cells incubated under aerobic growth conditions. Furthermore, DNA microarray and quantitative RT-PCR analyses revealed that the genes of several key enzymes of the glycolytic and organic acid production pathways, including gapA, pgk, tpi, ppc, IdhA and $m d h$, were significantly upregulated under oxygen deprivation conditions. The corresponding enzymic activities consistently correlated with the regulation patterns of the genetic expression observed at the transcriptional level. Studies of lac $Z$ fusions with the gap $A, I d h A$ and $m d h$ genes indicated not only that these genes are strongly induced at the onset of the stationary phase under aerobic growth conditions, but also that high expression levels are maintained under oxygen deprivation conditions. These results indicate that the genetic expression of several key metabolic enzymes in C. glutamicum cells incubated under oxygen deprivation conditions is chiefly regulated at the transcriptional level. The physiological consequence of the observed increased transcription under oxygen deprivation conditions is an increased rate of carbon source consumption, which is accompanied by a concomitant increase in organic acid production.
\end{abstract}

\section{INTRODUCTION}

Corynebacterium glutamicum is widely used as a costeffective bioconverter for the industrial production of numerous metabolites, including amino acids and organic

\footnotetext{
Abbreviations: DCW, dry cell weight; DO, dissolved oxygen; FUM, fumarase; GAPDH, glyceraldehyde-3-phosphate dehydrogenase; LDH, lactate dehydrogenase; $\mathrm{MDH}$, malate dehydrogenase; MOO, malate: quinone oxidoreductase; OAA, oxaloacetate; ORP, oxidation-reduction potential; PC, pyruvate carboxylase; PEPC, phosphoenolpyruvate carboxylase; PGK, phosphoglycerate kinase; $\mathrm{SDH}$, succinate dehydrogenase; TCA cycle, tricarboxylic acid cycle; TPI, triosephosphate isomerase.

The GenBank/EMBL/DDBJ accession nos for the complete $C$. glutamicum R genome DNA and native episome sequences are AP009044 and AP009045, respectively.

The array data discussed in this publication have been deposited in GenomeNet EXPRESSION (http://www.genome.jp/kegg/expression/) and are accessible through accession number ex0001754.

Tables showing oligonucleotides used in this study, expression data of genes observed to be up- or down-regulated under oxygen deprivation conditions, and the COGs functional annotation of genes and the numbers of genes showing increased or decreased transcriptional levels during oxygen deprived reactions, are available as supplementary data with the online version of this paper.
}

acids (Eggeling \& Sahm, 1999; Hermann, 2003; Inui et al., 1999a; Kelle et al., 2005; Kumagai, 2000; Vertès et al., 2005), as well as heterologous proteins (Billman-Jacobe et al., 1995; Salim et al., 1997). We previously observed that when aerobically grown C. glutamicum R (Yukawa et al., 2007) is packed to a high cell density under oxygen deprivation conditions, despite the cessation of cellular growth, the cells remain able to excrete in significant amounts several metabolites, including lactate and succinate (Inui et al., 2004b). There are two main advantages of using these oxygen deprivation conditions for the production of organic acids in corynebacteria. First, energy is primarily used for compound production, since microbial growth is essentially halted. This results in high yields and low by-product formation. Second, the absence of growth enables the use of micro-organisms at high density. This leads to high volumetric productivity.

The metabolism of C. glutamicum $\mathrm{R}$ for organic acid production has previously been investigated by measuring organic acid production, glucose consumption and intracellular $\mathrm{NAD}^{+} / \mathrm{NADH}$ ratios in the wild-type and various mutant strains in which the genes coding for key metabolic enzymes have been inactivated (Inui et al., 2004b). For Llactate production, glucose is metabolized to pyruvate via 
the glycolytic pathway. Pyruvate is in turn converted to L-lactate by the action of NAD-dependent lactate dehydrogenase (LDH). On the other hand, for succinate production, phosphoenolpyruvate, also metabolized from glucose, is converted to oxaloacetate (OAA) by the action of phosphoenolpyruvate carboxylase (PEPC), an anaplerotic enzyme. OAA is subsequently metabolized to succinate using the reductive arm of the tricarboxylic acid (TCA) cycle (i.e. OAA $\rightarrow$ malate $\rightarrow$ fumarate $\rightarrow$ succinate). The observation that under oxygen deprivation conditions PEPC is the predominant anaplerotic enzyme for succinate production (Inui et al., 2004b) is particularly noteworthy, as under aerobic conditions it is pyruvate carboxylase (PC) which is known to be the predominant anaplerotic enzyme to replenish OAA pools for the production of amino acids such as glutamate or lysine (Peters-Wendisch et al., 2001). In addition, the metabolism of C. glutamicum $\mathrm{R}$ under oxygen deprivation conditions is controlled mainly by the intracellular $\mathrm{NAD}^{+} / \mathrm{NADH}$ ratio. Moreover, bicarbonate or pyruvate addition into the oxygen deprived reaction can act as a trigger to stimulate the glycolytic pathway. This phenomenon is known as the 'pump-priming effect' (Inui et al., 2004b). Presumably, the uptake of extracellular pyruvate enables the regeneration of $\mathrm{NAD}^{+}$to fuel the glycolytic pathway at the glyceraldehyde-3-phosphate dehydrogenase (GAPDH) step.

To harness oxygen deprived metabolism in corynebacteria, we have developed a new, high-productivity bioprocess for organic acid production based on these observations (Inui et al., 2004b; Okino et al., 2005). Furthermore, we have recently applied this concept to the production of ethanol from recombinant C. glutamicum (Inui et al., 2004a).

The present study aims at a better understanding of the physiological mechanisms underlying the performance of C. glutamicum for organic acid and ethanol production under process conditions of oxygen deprivation, as controlled at the level of the regulation of genetic expression. We used global DNA microarrays to establish complete transcription profiles of the C. glutamicum genome, in which cells were incubated under normal aeration conditions in A rich medium at physiological cell densities and under oxygen deprivation conditions in BT minimal medium at very high cell densities. These incubation conditions are referred to in the rest of this manuscript as 'aerobic conditions' and 'oxygen deprivation conditions', respectively.

\section{METHODS}

Bacterial strains and plasmids. The bacterial strains and plasmids used in this study are listed in Table 1.

Chemicals. All chemicals were of the highest available purity, and were purchased from Wako Pure Chemical Industries or Sigma.

Conditions for growth and organic acid production. For genetic manipulations, Escherichia coli strains were grown at $37{ }^{\circ} \mathrm{C}$ in LuriaBertani (LB) medium (Sambrook et al., 1989) and C. glutamicum strains were grown at $33{ }^{\circ} \mathrm{C}$ in A medium $\left(2\right.$ g yeast extract $1^{-1}, 7 \mathrm{~g}$

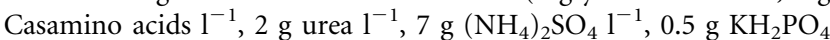
$\mathrm{l}^{-1}, 0.5 \mathrm{~g} \mathrm{~K}_{2} \mathrm{H}_{2} \mathrm{PO}_{4} \mathrm{l}^{-1}, 0.5 \mathrm{~g} \mathrm{MgSO}_{4} \cdot 7 \mathrm{H}_{2} \mathrm{O} \mathrm{l}^{-1}, 6 \mathrm{mg} \mathrm{Fe}_{2} \mathrm{SO}_{4} .7 \mathrm{H}_{2} \mathrm{O}$ $\mathrm{l}^{-1}, 4.2 \mathrm{mg} \mathrm{Mn} \mathrm{SO}_{4} \cdot \mathrm{H}_{2} \mathrm{O} \mathrm{l}^{-1}, 0.2 \mathrm{mg}$ biotin $\mathrm{l}^{-1}, 0.2 \mathrm{mg}$ thiamine $1^{-1}$ ) with $4 \%$ glucose on a rotary shaker at 200 r.p.m. When appropriate, media were supplemented with antibiotics. The final antibiotic concentrations for E. coli were $50 \mu \mathrm{g}$ tetracycline $\mathrm{ml}^{-1}$ and $50 \mu \mathrm{g}$ chloramphenicol $\mathrm{ml}^{-1}$; for C. glutamicum, the final antibiotic concentrations were $5 \mu \mathrm{g}$ chloramphenicol $\mathrm{ml}^{-1}$ and $50 \mu \mathrm{g}$ kanamycin $\mathrm{ml}^{-1}$.

Corynebacteria were cultivated at $33{ }^{\circ} \mathrm{C}, \mathrm{pH} 7.6$, for $13 \mathrm{~h}$ in $500 \mathrm{ml} \mathrm{A}$ medium containing $4 \%$ glucose in a 11 jar fermenter (BMJ01PI, Biott). The aeration was set at $11 \mathrm{~min}^{-1}$ and the agitation speed was 1000 r.p.m. The culture was harvested by centrifugation at $6500 \mathrm{~g}$ and $4{ }^{\circ} \mathrm{C}$ for $15 \mathrm{~min}$. The cell pellet was subsequently washed once with minimal medium (BT medium), which differs from the A medium by the absence of yeast extract and Casamino acids. For organic acid production under oxygen deprivation conditions, washed cells were resuspended at a final cell wet cell concentration of $50 \mathrm{~g} \mathrm{l}^{-1}$ with $80 \mathrm{ml}$ BT medium containing $200 \mathrm{mM}$ glucose and $400 \mathrm{mM}$ bicarbonate. The cell suspension was incubated at $33{ }^{\circ} \mathrm{C}$ with constant agitation without aeration in a lidded $100 \mathrm{ml}$ medium bottle. The $\mathrm{pH}$ of the cell reaction was maintained at 8 using a $\mathrm{pH}$ controller (DT-1023, Biott) to supplement the medium with $\mathrm{NH}_{3}$.

Analytical methods. Reaction mixtures were centrifuged $(1000 \mathrm{~g}$, $4{ }^{\circ} \mathrm{C}, 1 \mathrm{~min}$ ), and the supernatants were analysed for sugars and organic acids. Organic acids were quantified by HPLC (8020, Tosoh) equipped with an electric conductivity detector. The concentration of glucose was measured by an enzyme electrode glucose sensor (BF-4, Oji Scientific Instruments). Cell growth was monitored by measuring $\mathrm{OD}_{610}$ with a spectrophotometer (DU640, Beckman Coulter).

Detection methods for dissolved oxygen (DO) and oxidationreduction potential (ORP). The concentration of DO and the ORP were continuously monitored using an oxygen electrode (Type 12, Biott) and a Redox Fermprobe (Broadley-James), respectively.

Enzymic assays. Cultures were harvested by centrifugation at $5000 \mathrm{~g}$ and $4{ }^{\circ} \mathrm{C}$ for $10 \mathrm{~min}$. The cell pellet was washed once with extract buffer $\left(100 \mathrm{mM}\right.$ Tris/HCl, pH 7.5, $20 \mathrm{mM} \mathrm{KCl,} 20 \mathrm{mM} \mathrm{MgCl}_{2}$, $5 \mathrm{mM} \mathrm{MnSO}_{4}, 0.1 \mathrm{mM}$ EDTA, $2 \mathrm{mM}$ DTT). Cell suspensions were sonicated using an ultrasonic homogenizer (Astrason model XL2020) in an ice-water bath for three 2 min periods, interrupted by $2 \mathrm{~min}$ cooling intervals. Cell debris was removed by centrifugation $\left(10000 \mathrm{~g}, 4{ }^{\circ} \mathrm{C}, 30 \mathrm{~min}\right)$. The supernatant was used as a crude extract for enzyme assays. Protein concentrations were measured with a BioRad protein assay kit.

Assays for GAPDH (Omumasaba et al., 2004), phosphoglycerate kinase (PGK) (Eikmanns, 1992), triosephosphate isomerase (TPI) (Eikmanns, 1992), PEPC (Inui et al., 1997) and LDH (Bunch et al., 1997 ) were performed as previously described. Malate dehydrogenase (MDH) activity was determined as described by Sridhar et al. (2000), modified by using $0.1 \mathrm{M}$ Tris/ $\mathrm{HCl}(\mathrm{pH} 8.0)$ and $0.15 \mathrm{mM} \mathrm{NADH}$ to obtain optimum enzyme activities. $\beta$-Galactosidase activities were measured as described previously (Inui et al., 1999b).

DNA techniques. Plasmid DNA was isolated by the alkaline lysis procedure (Sambrook et al., 1989) or by using a HiSpeed Plasmid Midi kit (Qiagen) according to the manufacturer's instructions, modified, when extracting DNA from corynebacteria, by using $4 \mathrm{mg}$ lysozyme $\mathrm{ml}^{-1}$ at $37{ }^{\circ} \mathrm{C}$ for $30 \mathrm{~min}$. Chromosomal DNA was isolated from corynebacteria following the method of Sambrook et al. (1989), modified by using $4 \mathrm{mg}$ lysozyme $\mathrm{ml}^{-1}$ at $37^{\circ} \mathrm{C}$ for $30 \mathrm{~min}$. Restriction endonucleases and Klenow fragment were purchased from Takara and used as per the manufacturer's instructions. PCR was 
Table 1. Bacterial strains and plasmids used in this study

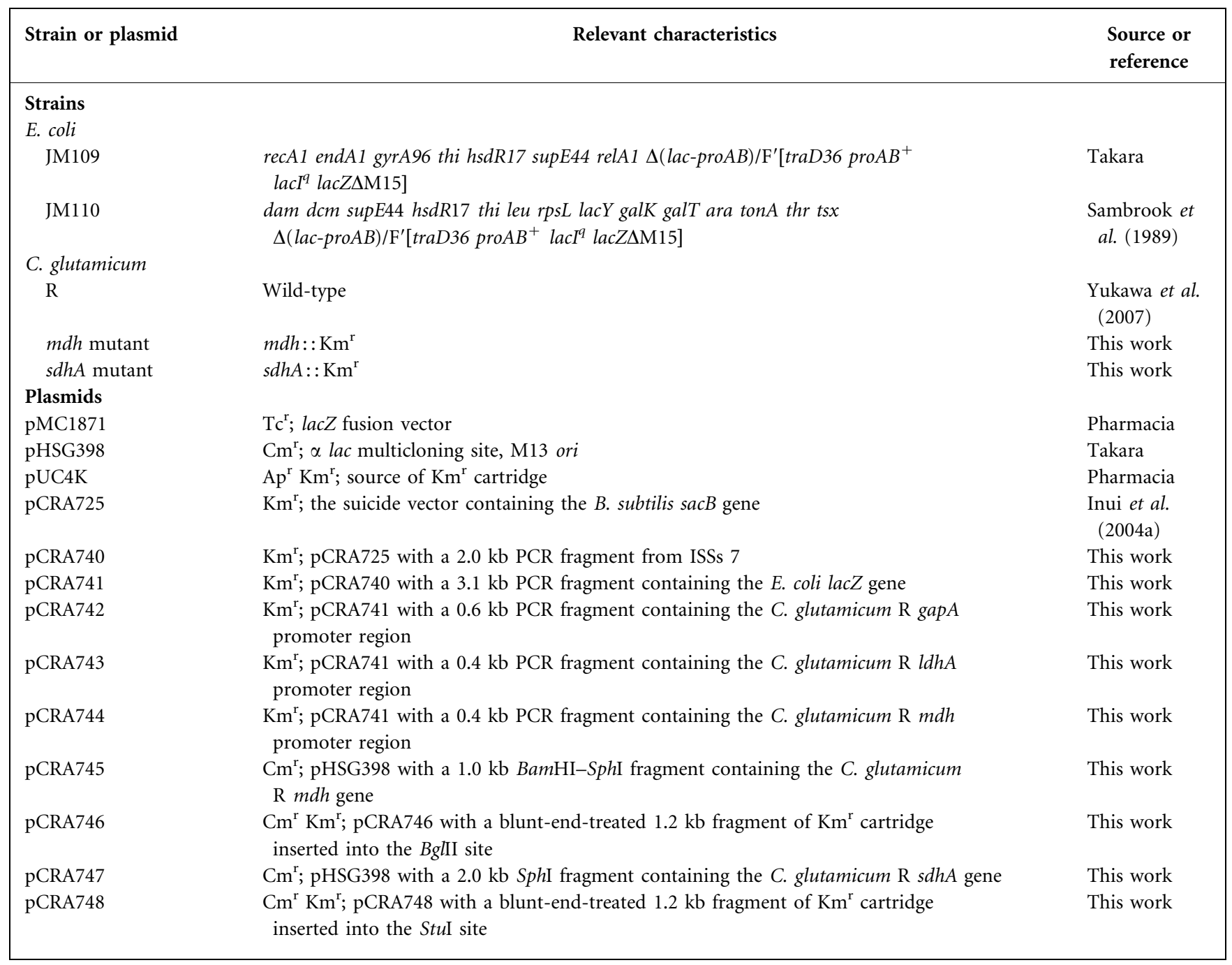

performed using an Applied Biosystems GeneAmp PCR System 9700 in a total volume of $100 \mu \mathrm{l}$ with $50 \mathrm{ng}$ chromosomal DNA, $0.5 \mu \mathrm{M}$ each primer, $0.2 \mathrm{mM}$ dNTP, $2 \%$ DMSO in ExTaq polymerase buffer with $\mathrm{MgCl}_{2}$ and $4 \mathrm{U}$ ExTaq DNA polymerase (Takara) for 30 cycles at temperatures of $94{ }^{\circ} \mathrm{C}$ for denaturation $(1 \mathrm{~min}), 55^{\circ} \mathrm{C}$ for annealing ( $1 \mathrm{~min})$, and $72{ }^{\circ} \mathrm{C}$ for extension $(2 \mathrm{~min})$. The PCR fragments were purified with a QIAquick PCR purification kit (Qiagen).

Corynebacteria were transformed by electroporation as previously described (Vertès et al., 1993a). Transformation of E. coli cells was performed by the $\mathrm{CaCl}_{2}$ procedure, as described by Sambrook et al. (1989).

Preparation of DNA microarray. PCR primers (20-mers) were designed to amplify the full-length coding DNA segments of 3080 predicted ORFs based on the annotation of the complete $C$. glutamicum R genome sequence (Yukawa et al., 2007). Aminoterminus primers amplified $20 \mathrm{bp}$ downstream from the initiation codon, which was included. Carboxy-terminus primers amplified $20 \mathrm{bp}$ upstream from the termination codon, which also was included. The ORF-specific double-stranded DNA fragments were produced by standard PCR amplification methods, as described above, with genomic DNA of C. glutamicum R as template and the above primer sets. Each PCR product was analysed routinely by agarose gel electrophoresis to ensure its size and purity. When PCR products of the expected size or purity were not obtained, modification of PCR conditions, redesign of primer pairs, or purification of DNA fragments from gels were attempted. As a result, a library of 3076 single PCR products was obtained that contained $99.9 \%$ of a total of 3080 predicted ORFs present in the C. glutamicum $\mathrm{R}$ genome. PCR products were purified by a PCR96 Cleanup kit (Millipore), desiccated and resuspended in Solution-T (Takara Bio). The PCR products thus obtained were printed in duplicate at two separate positions onto a $1 \times 3$ inch $(2.5 \times 7.5 \mathrm{~cm}$ approx.) Takara slide glass TX704 (Takara Bio) using an arraying robot. The DNA microarrays were rehydrated in a humidity chamber at $37^{\circ} \mathrm{C}$ for $1 \mathrm{~h}$. They were subsequently exposed to UV light at an energy setting of $60 \mathrm{~mJ} \mathrm{~cm} \mathrm{~cm}^{-2}$ in a UV cross-linker, and soaked in $0.2 \%$ SDS for 2 min at room temperature. After being washed twice with ultrapure water, the slides were immersed in a succinic anhydride solution for $20 \mathrm{~min}$ at room temperature, and placed in boiling water for $2 \mathrm{~min}$. The slides were then immersed in $100 \%$ ethanol for $1 \mathrm{~min}$ and dried by centrifugation at $185 \mathrm{~g}$ for $2 \mathrm{~min}$. Spotting quality was assessed by checking as controls the configuration and concentration of nonspecific stained DNA spots on the DNA microarrays. In addition, 12 spots each of human transferrin receptor $(1 \mathrm{~kb})$, E. coli plasmid pUC19 and 2 DNA were printed onto the slides as negative controls 
for DNA hybridization. DNA microarrays were stored at room temperature in the dark under controlled-humidity conditions until use.

RNA isolation. Total RNA was extracted from C. glutamicum R cells using the Qiagen RNeasy Midi kit. Cultures were added to two volumes of RNAprotect Bacteria reagent (Qiagen), incubated for $5 \mathrm{~min}$, and centrifuged at 3000 r.p.m. for $5 \mathrm{~min}$ at room temperature. The pellet was resuspended in RLT buffer containing $\beta$-mercaptoethanol (RNeasy Midi kit, Qiagen) to a final concentration of $1 \mathrm{~g}$ dry cell weight (DCW) per litre. A $1 \mathrm{ml}$ sample of this cell suspension was subsequently mixed with $0.5 \mathrm{~g} 0.1 \mathrm{~mm}$ zirconia/silica beads (BioSpec Products). Cells were mechanically disrupted for eight cycles of $45 \mathrm{~s}$ at a speed rating of 6.5 spaced by 5 min resting intervals in a FastPrep FP120 instrument (Qbiogene). The resulting mixture was centrifuged for $5 \mathrm{~min}$ at 15000 r.p.m. The supernatant was processed using an RNeasy system (Qiagen) with DNase on-column treatment according to the manufacturer's instructions for RNA extraction. Isolated RNA samples were checked for purity by both agarose gel electrophoresis and spectrophotometric analysis, and stored at $-80{ }^{\circ} \mathrm{C}$ until use.

Preparation of labelled cDNA. Fluorescently labelled cDNAs were prepared by cDNA synthesis with random nonamer primers and $30 \mu \mathrm{g}$ total RNA of C. glutamicum $\mathrm{R}$ as template, with subsequent Cy3/Cy5 labelling, using a CyScribe cDNA Post-Labelling kit (Amersham Biosciences), according to the manufacturer's instructions.

Hybridization and analysis. Fifty microlitres of each Cy3- and Cy5labelled cDNA probe, prepared as mentioned above, was mixed and added to $100 \mu \mathrm{l} 2 \times$ hybridization buffer $[12 \times$ saline sodium citrate (SSC), $0.4 \%$ SDS, $10 \times$ Denhardt's solution, $0.2 \mathrm{mg} \mathrm{ml}^{-1}$ denatured salmon sperm DNA]. All steps, from hybridizing to washing and drying, were automatically performed using a Lucidea Automated Slide Processor (Amersham Biosciences). The hybridization solution, which was heated at $95{ }^{\circ} \mathrm{C}$ for $2 \mathrm{~min}$ and cooled to room temperature, was added to hybridization buffer to a final combined volume of $200 \mu$ l. The DNA microarray was inserted into the Lucidea Automated Slide Processor and hybridization at $60{ }^{\circ} \mathrm{C}$ with the whole-genome DNA microarray was allowed to proceed for $14 \mathrm{~h}$. The hybridization arrays were subsequently washed (once at $35{ }^{\circ} \mathrm{C}$ for $6 \mathrm{~min}$ in $2 \times$ SSC and $0.2 \% \mathrm{SDS}$, once at $35{ }^{\circ} \mathrm{C}$ for $6 \mathrm{~min}$ in $0.2 \times$ SSC and $0.2 \%$ SDS), rinsed (twice at $35{ }^{\circ} \mathrm{C}$ in $0.2 \times$ SSC and once at $37{ }^{\circ} \mathrm{C}$ in isopropanol) and dried. The slides were scanned at $532 \mathrm{~nm}$ for $\mathrm{Cy} 3$ and at $635 \mathrm{~nm}$ for Cy5 with a Fujifilm Fluorescent Image Analyser FLA-8000 (Fuji). Images were analysed with a GenePix Pro 5.0 instrument (Axon Instruments). Individual spots were located, the Cy3 and Cy5 fluorescence intensity at each spot was measured, and the background signal intensities were determined. Artefacts on slides such as dust, scratches or salts were excluded from further analysis. Data analysis was performed using GeneSpring 6.1 software (Silicon Genetics). The data generated by GenePix 5.0 were loaded to GeneSpring 6.1 and normalized by global normalization and intensity-dependent LOWESS normalization to eliminate Cy dye bias. The normalization parameter selected in the GeneSpring 6.1 software was 'Per spot and per chip: intensity dependent (LOWESS) normalization'. The resultant raw intensity data were consecutively calculated as Cy3/Cy5 ratios that represented the average of a total of 12 hybridization signals for each gene: duplicate spots on six different slides of six replicate RNA samples from six independent biological samples. Negative controls consistently gave hybridization signals that were similar to the background. Estimated differences were considered significant if the $P$ value of a $t$ test was $<0.05$.

Quantitative RT-PCR. Quantitative RT-PCR was performed using an ABI PRISM 7000 Sequence Detection System (Applied Biosystems) and a QuantiTect SYBR Green RT-PCR kit (Qiagen) according to the manufacturer's instructions. Specific primers (primers 1-40 and 6681) (Supplementary Table S1) were designed by the Primer Express Software version 2.0 (Applied Biosystems). Each PCR reaction consisted of $25 \mu \mathrm{l} 2 \times$ QuantiTect SYBR Green RT-PCR Master Mix, $0.5 \mu \mathrm{M}$ forward primer, $0.5 \mu \mathrm{M}$ reverse primer, $0.5 \mu \mathrm{l}$ QuantiTect RT Mix and $50 \mathrm{ng}$ total RNA in a total volume of $50 \mu$ l. PCR parameters were $50{ }^{\circ} \mathrm{C}$ for $30 \mathrm{~min}, 95^{\circ} \mathrm{C}$ for $15 \mathrm{~min}$, and 45 cycles at $95{ }^{\circ} \mathrm{C}$ for $15 \mathrm{~s}, 55^{\circ} \mathrm{C}$ for $30 \mathrm{~s}, 72{ }^{\circ} \mathrm{C}$ for $30 \mathrm{~s}$. The comparative $\mathrm{C}_{\mathrm{T}}$ method (Applied Biosystems) was used to quantify relative expression, with a threshold cycle $\left(\mathrm{C}_{\mathrm{T}}\right)$ being defined as the cycle at which the reporter fluorescence is distinguishable from the background in the extension phase of the PCR reaction. The $\mathrm{C}_{\mathrm{T}}$ values were computed as the mean of triplicates.

Construction of gapA-, IdhA- and mdh-lacZ fusions. $\beta$ Galactosidase was expressed as hybrid $g a p A^{\prime}-$, $l d h A^{\prime}-$ and $m d h^{\prime}-$ 'lacZ fusion proteins, using the native gapA, $l d h A$ and $m d h$ transcriptional and translational signals, respectively. In order to integrate the fusion genes on the C. glutamicum $\mathrm{R}$ chromosome by homologous recombination, a $2.0 \mathrm{~kb}$ DNA fragment from the strainspecific island 7 (SSI 7) (Suzuki et al., 2005) of C. glutamicum R was amplified using the two oligonucleotide primers 41 and 42 with $C$. glutamicum R chromosomal DNA as template. The $2.0 \mathrm{~kb}$ PCR product was digested with $S p h \mathrm{I}$, and inserted into the unique $S p h \mathrm{I}$ site of the suicide vector pCRA725, yielding pCRA740. The E. coli lacZ gene was amplified using oligonucleotide primers 43 and 44 with the E. coli lacZ fusion vector pMC1871 as template. The $3.1 \mathrm{~kb}$ PCR product containing the E. coli lacZ was digested with NheI, and inserted into the unique NheI site of pCRA740, yielding pCRA741. In order to amplify the gapA promoter region, the oligonucleotide primers 45 and 46 were used in a PCR with C. glutamicum R chromosomal DNA as template. The $0.6 \mathrm{~kb}$ PCR product encompassing the gapA promoter region was digested with NaeI, and inserted into the unique NaeI site of pCRA741, yielding pCRA742. Similarly, the C. glutamicum $l d h A$ and $m d h$ promoter regions were amplified by PCR using their respective oligonucleotide primers (primers 47-50) and C. glutamicum R chromosomal DNA as template. Each amplified PCR product was cloned into pCRA741, yielding pCRA743 for the ldhA-lacZ fusion and pCRA744 for the $m d h$-lacZ fusion (Table 1). The plasmids pCRA742, pCRA743 and pCRA744 were isolated as non-methylated DNA from E. coli JM110 for efficient gene introduction into C. glutamicum $\mathrm{R}$ (Vertès et al., 1993a), and were subsequently integrated on the C. glutamicum $\mathrm{R}$ chromosome by markerless gene insertion methods, as described previously (Inui et al., 2004a).

Primer extension. IRD700-labelled primers (primers 51-61) were designed as shown in Supplementary Table S1. Total RNA $(100 \mu \mathrm{g})$ and $1.5 \mathrm{pmol}$ primer were mixed and annealed at $80{ }^{\circ} \mathrm{C}$ for $90 \mathrm{~min}$, at $60{ }^{\circ} \mathrm{C}$ for $90 \mathrm{~min}$ and at $30{ }^{\circ} \mathrm{C}$ for $90 \mathrm{~min}$, using a GeneAmp PCR System 9700 instrument (Applied Biosystems). cDNA was synthesized at $42{ }^{\circ} \mathrm{C}$ for $1 \mathrm{~h}$ using AMV Reverse Transcriptase (Promega). The reaction was terminated by adding EDTA ( $\mathrm{pH} 8.0$ ) at a final concentration of $250 \mathrm{mM}$ and DNase-free RNase A at a final concentration of $3 \mathrm{ng} \mu \mathrm{l}^{-1}$ to trigger degradation of the RNA templates. The resulting cDNA was treated by phenol/chloroform extraction and ethanol precipitation. Upon centrifugation, the precipitated DNA pellet was resuspended in IR2 Stop Solution (LICOR). The primer extension products were treated at $95{ }^{\circ} \mathrm{C}$ for $2 \mathrm{~min}$ and placed on ice for $5 \mathrm{~min}$, and separated on $3.7 \% \mathrm{~KB}^{\text {Plus }}$ Gel Matrix (LI-COR) using a LI-COR 4300 DNA analyser. The migration position of each primer extension product was determined by comparing a sequencing ladder generated from a DNA fragment corresponding to the same chromosomal region, using the same primers and a DYEnamic Direct Cycle Sequencing kit with 7-deazadGTP (Amersham Biosciences). 
(a)

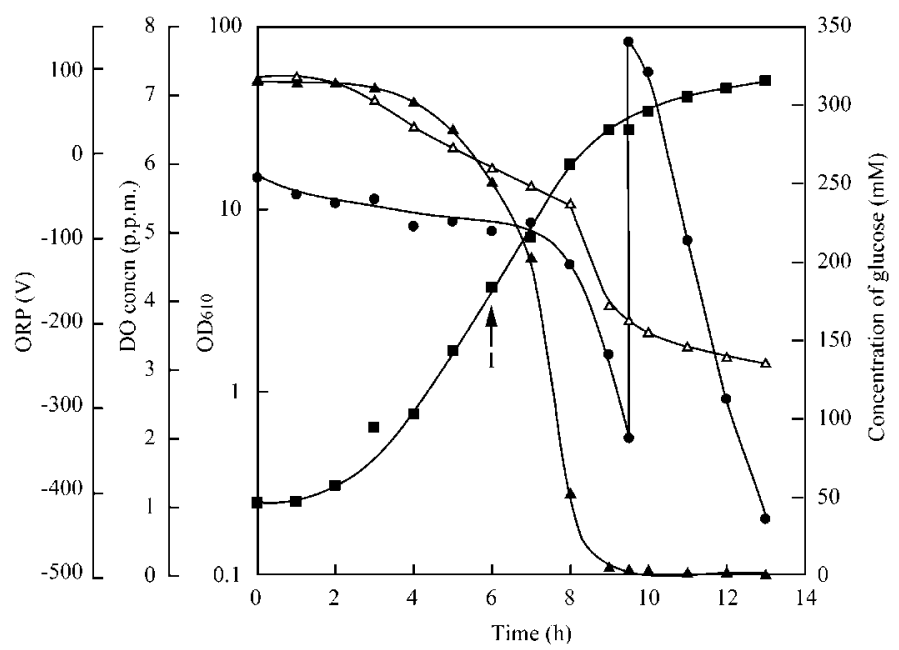

(b)

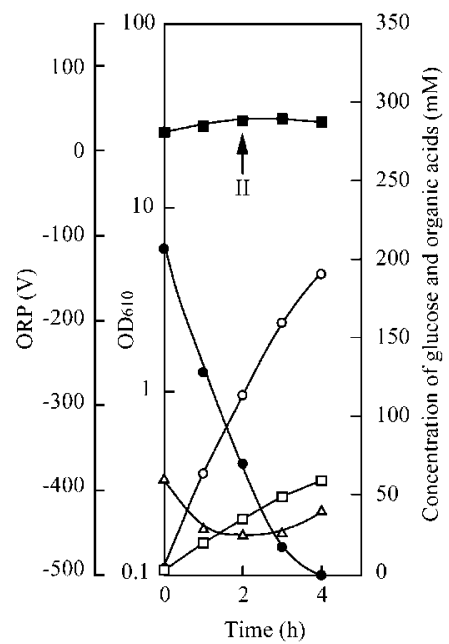

Fig. 1. Time-course of aerobic cultivation and oxygen deprived conditions, and sampling of C. glutamicum cells. Cell density $(\boldsymbol{\square}), \mathrm{DO}(\boldsymbol{\Delta})$ and $\operatorname{ORP}(\triangle)$, and the concentration of glucose $(\bullet)$, lactate $(\bigcirc)$ and succinate $(\square)$ during aerobic cultivation (a) and oxygen deprived conditions (b) of C. glutamicum R. The arrows indicate the sampling points of C. glutamicum cells under aerobic (I) and oxygen deprivation conditions (II) for transcriptional analyses. Under oxygen deprivation conditions, the DO value was always maintained at a level lower than 0.01 p.p.m. A glucose spike was performed at $9.5 \mathrm{~h}$ after the beginning of the experiment by adding $20 \mathrm{~g}$ glucose to the reaction vessel containing $500 \mathrm{ml}$ culture.

Gene disruption and replacement of the $m d h$ and sdhA genes. Based on the C. glutamicum $\mathrm{R}$ whole genome sequence (Yukawa et al., 2007), two oligonucleotide primers were designed to amplify a portion of the $m d h$ gene (Supplementary Table S1). The oligonucleotide primers 62 and 63 were used in a PCR with C. glutamicum R chromosomal DNA as template. The $1.0 \mathrm{~kb}$ PCR product bearing the $m d h$ gene was digested with BamHI and SphI, and inserted into the unique BamHI-SphI site of the E. coli vector pHSG398, which cannot replicate in C. glutamicum, yielding pCRA745. A $1.2 \mathrm{~kb}$ PstI kanamycin cassette from pUC4K was blunt-ended with the Takara DNA blunting kit according to the manufacturer's instructions and subsequently inserted into the blunt-ended unique BglII site that lies within the $m d h$ gene-coding region borne by plasmid pCRA745. The resulting plasmid pCRA746 was electroporated into C. glutamicum R according to the method that uses non-methylated DNA isolated from E. coli, as reported previously (Vertès et al., 1993b). Similarly, the C. glutamicum sdhA gene was amplified by PCR using the oligonucleotide primers 64 and 65, and C. glutamicum R chromosomal DNA as template (Supplementary Table S1). The amplified PCR product was cloned into the E. coli vector pHSG398, yielding pCRA747. A $1.2 \mathrm{~kb}$ blunt-ended kanamycin cassette was inserted into the unique StuI site of the $s d h A$ gene on pCRA747. The resulting plasmid pCRA748 was electroporated into C. glutamicum $\mathrm{R}$ to generate an $s d h A$-deficient mutant. Disruptions of the two genes were confirmed by Southern hybridization and PCR analyses.

\section{RESULTS}

\section{Transcriptome analysis of C. glutamicum during organic acid production under oxygen deprived conditions}

Fig. 1 shows the time-course of the aerobic cultivation of $C$. glutamicum in a 11 jar fermenter followed by its incubation under conditions of oxygen deprivation accompanied by the production of organic acid. We have previously reported that C. glutamicum cells produce organic acids from glucose at high yields in mineral medium, even though their proliferation is arrested (Inui et al., 2004b; Okino et al., 2005). Here, we confirmed that the glucose consumption rate during an oxygen deprived reaction [8.1 mmol (g DCW $)^{-1} \mathrm{~h}^{-1}$ ] (Fig. 1b) was 1.4-fold higher than that attained during aerobic cultivation $[6.0 \mathrm{mmol}(\mathrm{g}$ DCW $)^{-1} h^{-1}$ ] (Fig. 1a). This phenomenon, which occurs in numerous organisms subjected to anaerobic conditions, is known as the 'Pasteur effect' (Emmerling et al., 2000; Gottschalk, 1985).

In order to investigate the metabolic and molecular changes occurring at the transcriptional level when cells are shifted from aerobic cultivation to incubation under production-process conditions of oxygen deprivation without growth, we studied the global genetic expression pattern of C. glutamicum using DNA microarrays. Six independent DNA microarray experiments were performed to generate statistically significant data points that were satisfactory for gene expression analysis. Furthermore, profiling data for the genes coding for proteins involved in the glycolytic pathway, TCA cycle and $\mathrm{H}^{+}$-ATPase were all verified by RT-PCR. Mid-exponential-phase cells were harvested after $6 \mathrm{~h}$ aerobic cultivation at a DO concentration of 5.7 p.p.m (ORP $-17 \mathrm{mV}$ ) (Fig. 1a), and after $2 \mathrm{~h}$ incubation under oxygen deprivation conditions at a DO concentration of $<0.01$ p.p.m (ORP $-451 \mathrm{mV})$ (Fig. 1b) for DNA microarray analysis. 


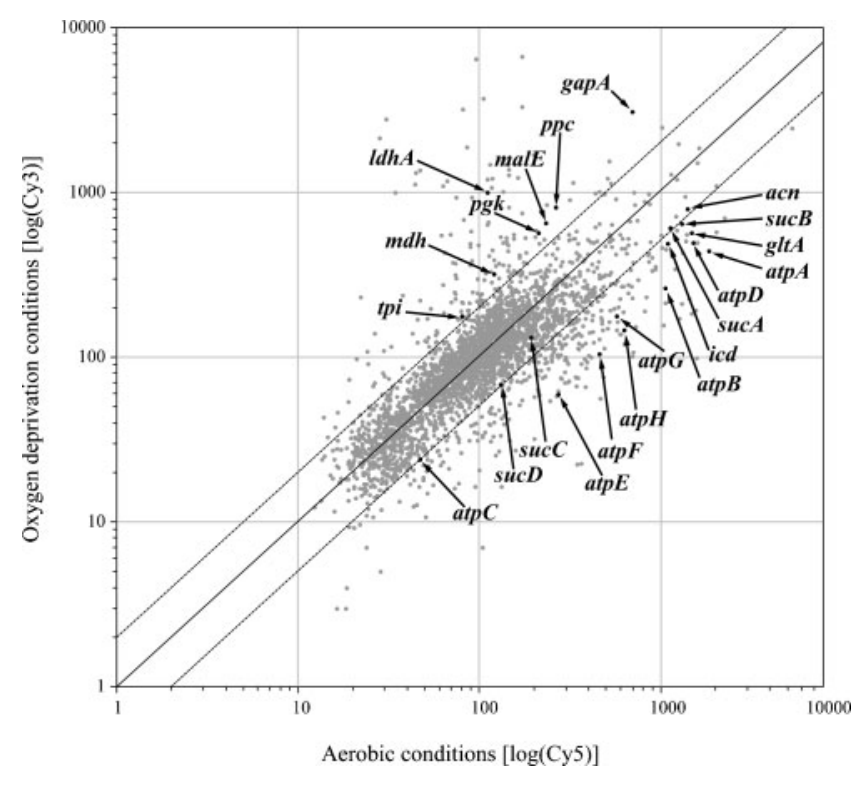

Fig. 2. Scatter plot of $\log ($ Су 3$)$ - and $\log ($ Сy5)-derived fluorescence. Each dot represents the mean of six different experiments of duplicate spots of the same sample. The RNA of $C$. glutamicum $\mathrm{R}$ cells grown under aerobic conditions and without growth under oxygen deprivation conditions was used for Cy5 and Cy3 labelling. The two outer lines demarcate values for significant difference (two- and one-half-fold) in gene expression relative to the central line (no change in expression). The positions of several key enzyme-encoding genes ( $g a p A, p g k, t p i, p p c, I d h A, m d h, m a l E$, gltA, acn, icd, sucA, sucB, sucC, sucD, atpB, atpE, atpF, atpH, $\operatorname{atp} A, \operatorname{atp} G, \operatorname{atp} D$ and $\operatorname{atp} C)$ are indicated.

The ratios of mRNA levels in the cells under oxygen deprivation conditions relative to those attained under aerobic conditions were calculated by comparing normalized signal intensities between the two samples. The scatter plot of the resulting data showed a correlation coefficient of 0.37 , demonstrating that significant changes in the gene expression profiles were taking place between the two conditions (Fig. 2). A total of 161 genes showed a greater than twofold increase in expression, and 221 genes were transcribed at levels less than half those observed under aerobic conditions (Supplementary Table S2). Using the nomenclature based on gene function as defined by the NCBI COG (Clusters of Orthologous Groups) database, 62 of the observed 161 upregulated genes and 64 of the observed 221 down-regulated genes belonged to the metabolism category, suggesting a profound change had occurred when cells were shifted from aerobic conditions to oxygen deprivation conditions (Supplementary Table S3). We focused our detailed analysis on the expression of genes coding for proteins involved in glycolysis, the anaplerotic pathway and the TCA cycle that are related to organic acid production under oxygen deprivation conditions. Several key enzyme-encoding genes in the glycolytic and anaplerotic pathways, and the reductive arm of the TCA cycle, were more than twofold upregulated
(Table 2, Figs 2 and 3). In contrast, most genes in the oxidative arm of the TCA cycle (pyruvate $\rightarrow$ citrate $\rightarrow$ isocitrate $\longrightarrow$ oxoglutarate $\longrightarrow$ succinyl-CoA $\rightarrow$ succinate) were down-regulated (Table 2, Figs 2 and 3).

It has been demonstrated in previous work that in $C$. glutamicum, glycolysis under oxygen deprivation conditions is controlled at least in part by the intracellular $\mathrm{NAD}^{+} / \mathrm{NADH}$ ratio. This conclusion is particularly based on the observation that the gapA gene, which encodes the enzyme GAPDH, is inhibited by NADH (Inui et al., 2004a, b; Omumasaba et al., 2004). Moreover, under oxygen deprivation conditions for succinate production by $C$. glutamicum, the major anaplerotic reaction is driven by the $p p c$ gene product PEPC, rather than by the $p y c$ gene product PC (Inui et al., 2004b). The gapA and $p p c$ genes form, with the $p g k$ and tpi genes, a cluster in the $C$. glutamicum genome (Eikmanns, 1992). Consistent with these previous observations, we observed during the present study that these four genes were highly upregulated at the transcriptional level under oxygen deprivation conditions (Table 2, Figs 2 and 3). Furthermore, the $l d h A$ gene, which codes for the enzyme LDH, was 8.6-fold induced at the transcriptional level under oxygen deprivation conditions (Table 2, Figs 2 and 3). Likewise, the $m d h$ gene coding for $\mathrm{MDH}$, an enzyme of the reductive arm of the TCA cycle, was 2.7-fold upregulated at the transcriptional level (Table 2, Figs 2 and 3). We have previously reported that C. glutamicum fum (fumarase; FUM) gene disruptants are unable to produce succinate (Inui et al., 2004b). Similarly, we observed during the course of this work that two C. glutamicum mutants in which the MDHencoding gene $(m d h)$ or the succinate dehydrogenase (SDH) encoding gene $(s d h A)$ had been disrupted were unable to produce succinate. These data indicate that $\mathrm{MDH}, \mathrm{FUM}$ and SDH are all necessary for succinate production. Related to this finding, the fum, $s d h A, s d h B$ and $s d h C$ genes coding for enzymes of the reductive arm of the TCA cycle were all down-regulated under oxygen deprivation conditions (Table 2, Fig. 3). In addition, we have previously reported that overexpression in a $C$. glutamicum ldhA mutant of the E. coli frdABCD genes, encoding the enzyme fumarate reductase, which catalyses the conversion of fumarate to succinate, leads to a marginal albeit consistent increase in succinate production when cells are incubated under oxygen deprivation conditions (Murakami et al., 2005). Thus, it was interesting that the malE gene, coding for the malic enzyme, was twofold overexpressed under oxygen deprivation conditions compared to aerobic conditions (Table 2, Figs 2 and 3). It was also noted that the gltA, acn, icd, sucA, sucB, sucC and sucD genes, which encode enzymes involved in the oxidative arm of the TCA cycle, were all down-regulated to approximately half to two-thirds of their expression levels under standard aeration conditions (Table 2, Figs 2 and 3). Moreover, the transcriptional expression of the aceA and aceB genes, respectively coding for isocitrate lyase and malate synthase, two enzymes of the glyoxylate shunt, were not significantly 
Table 2. Expression data of C. glutamicum $\mathrm{R}$ genes in the glycolytic pathway, TCA cycle and $\mathrm{H}^{+}$-ATPase

-, Not determined.

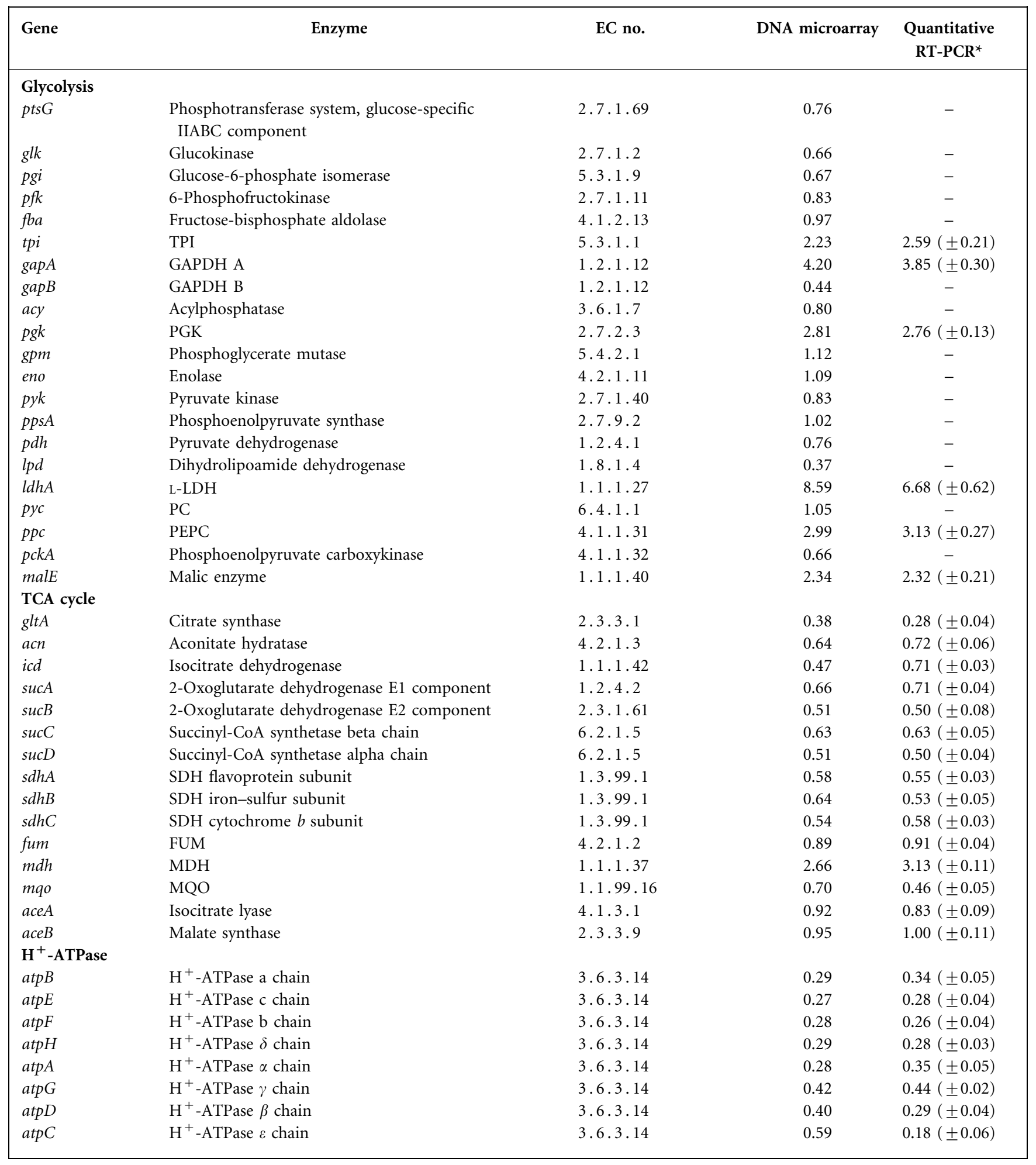

${ }^{\star}$ The values are mean \pm SD for three independent determinations. 


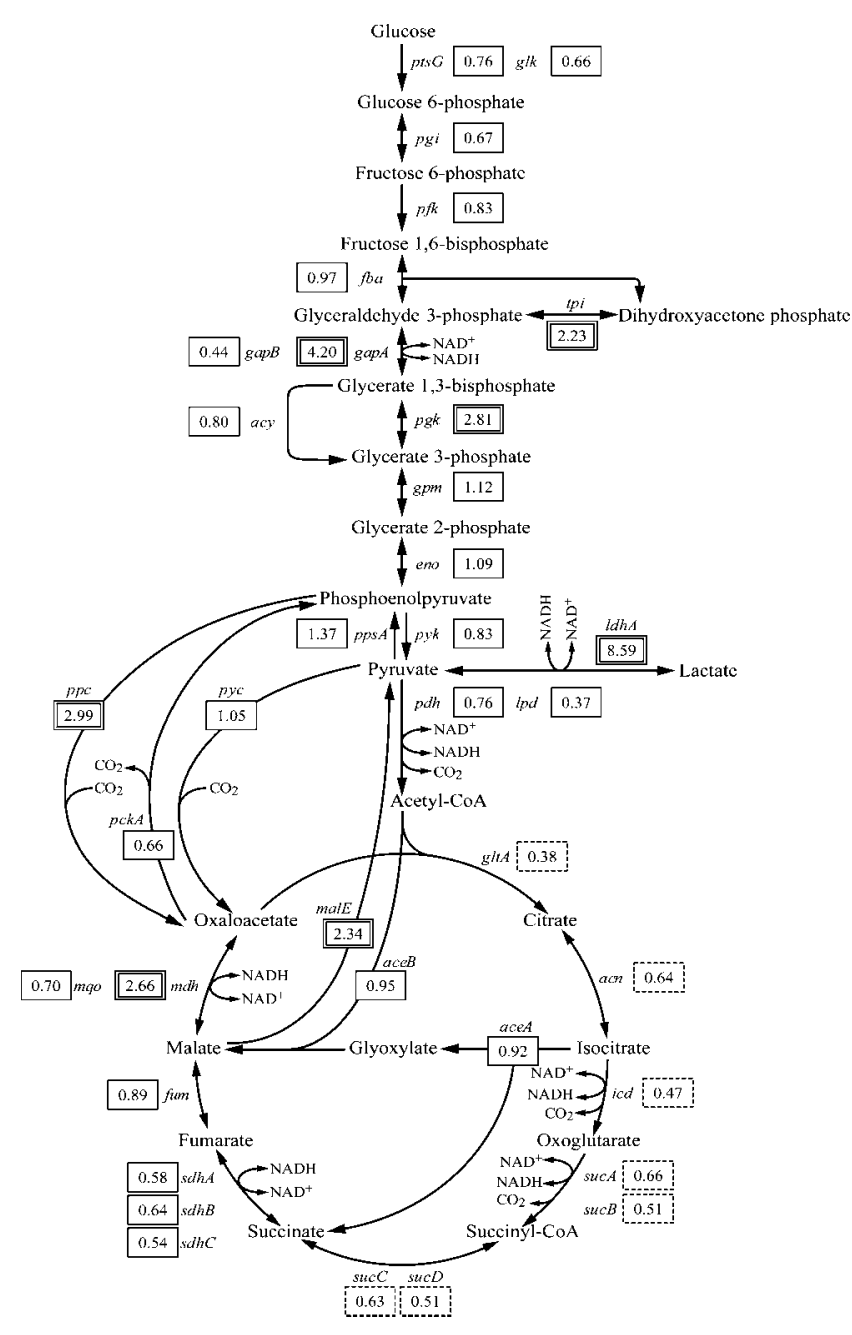

Fig. 3. Schematic representation of the glycolytic pathway and the TCA cycle exhibiting, relative to aerobic conditions, the mRNA levels of various genes in these pathways in cells incubated under oxygen deprivation conditions. The induction magnitudes for genes are reported in boxes. Double boxes indicate that the expression level was more than twofold increased; dotted boxes indicate down-regulated genes in the oxidative arm of the TCA cycle. The nomenclature of genes and their enzymes is shown in Table 2.

changed under oxygen deprivation compared to aerobic conditions (Table 2, Fig. 3). We have previously reported the absence of gas release by C. glutamicum during organic acid production under oxygen deprivation conditions (Inui et al., 2004b) and that similar amounts of succinate are produced by aceA mutants compared to the wild-type (Inui et al., 2004b). Together, these data corroborated the view that under oxygen deprivation conditions, $C$. glutamicum scarcely used either the forward direction of the TCA cycle, which is known to release $\mathrm{CO}_{2}$ at several enzymic steps, or the glyoxylate shunt.

The DNA microarray data collected in this work were confirmed by quantitative RT-PCR analyses (Table 2).
Table 3. Enzymic activities of C. glutamicum $\mathrm{R}$ under aerobic and oxygen deprivation conditions

\begin{tabular}{|lcc|}
\hline Enzyme & $\begin{array}{c}\text { Specific activity } \\
(\text { mg protein })^{-1} \text { ] }\end{array}$ \\
\cline { 2 - 3 } & Aerobic conditions & $\begin{array}{c}\text { Oxygen deprivation } \\
\text { conditions }\end{array}$ \\
\hline GAPDH & $4.9( \pm 0.1) \times 10^{2}$ & $2.6( \pm 0.2) \times 10^{3}$ \\
PGK & $2.0( \pm 0.2) \times 10^{2}$ & $2.1( \pm 0.3) \times 10^{3}$ \\
TPI & $2.3( \pm 0.3) \times 10$ & $4.4( \pm 0.5) \times 10^{2}$ \\
PEPC & $8.7( \pm 0.5) \times 10$ & $3.9( \pm 0.3) \times 10^{2}$ \\
LDH & $1.0( \pm 0.2) \times 10$ & $1.4( \pm 0.2) \times 10^{2}$ \\
MDH & $1.2( \pm 0.1) \times 10^{2}$ & $3.1( \pm 0.2) \times 10^{3}$ \\
\hline
\end{tabular}

*The values are mean $\pm \mathrm{SD}$ for three independent determinations.

Furthermore, the increased gene expression at the transcriptional level was reflected in the corresponding specific enzyme activities when these were measured in parallel (Table 3). The ratios of the activities of the enzymes TPI and $\mathrm{MDH}$ when shifted from aerobic to oxygen deprivation conditions were notably higher than the ratios of their corresponding gene expression by the DNA microarray analysis (Tables 2 and 3). To understand the difference, additional analyses under oxygen deprivation conditions of mRNA stability, the efficiency and control of translation, and protease activity towards the enzymes, are needed.

DNA microarray and quantitative RT-PCR analyses furthermore revealed that transcription under oxygen deprivation conditions of the entire $\mathrm{H}^{+}$-ATPase operon (including atpB, atpE, atpF, atpH, atpA, atpG atpD and atpC) is dramatically down-regulated to one-quarter to one-half of the levels attained under aerobic conditions (Table 2). These data suggest the existence of a correlation between reduced $\mathrm{H}^{+}$-ATPase activity in C. glutamicum under oxygen deprivation conditions and enhanced glycolytic metabolism, as seen in $\mathrm{H}^{+}$-ATPase mutants of E. coli (Jensen \& Michelsen, 1992; Jensen et al., 1995), Bacillus subtilis (Santana et al., 1994) and C. glutamicum (Sekine et al., 2001).

\section{Effect of oxygen tension on expression of the gapA gene cluster, and the $I d h A$ and $m d h$ genes}

The differences in transcriptional profiles between aerobic cultivation in A medium and the oxygen deprived reaction in BT medium could alternatively be explained by nutrient limitation, not simply oxygen tension. To verify whether the expression of the gapA gene cluster, and the $l d h A$ and $m d h$ genes, which were more than twofold upregulated in the above DNA microarray and quantitative RT-PCR analyses, were regulated via oxygen tension, we observed the changes of the expression of gapA, $p g k, t p i, p p c, l d h A$ and $m d h$ genes by supplying nitrogen gas during aerobic growth. 


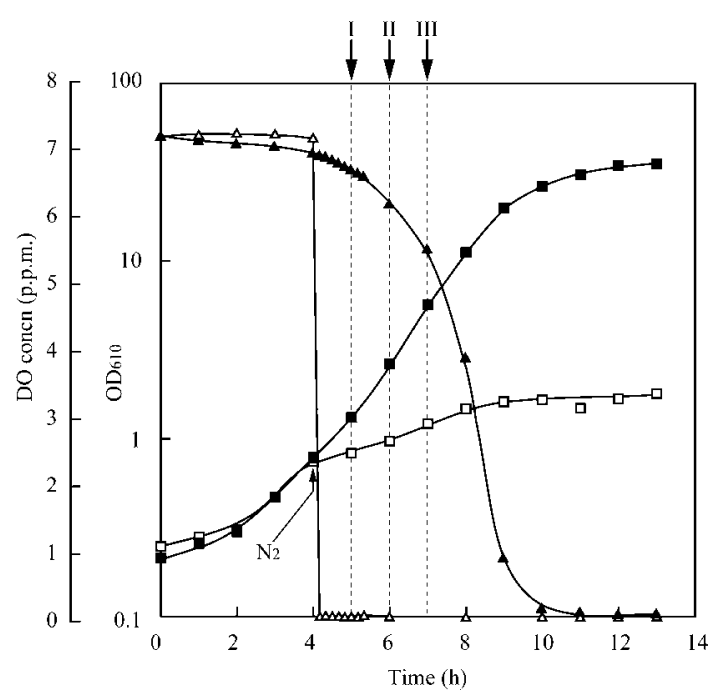

Fig. 4. Effect of supplying nitrogen gas during aerobic growth on the growth profile of C. glutamicum cells and the DO concentration. The cell density with air supply ( $\boldsymbol{\square}$ ) and the concomitant DO $(\mathbf{\Delta})$, and the cell density after supplying nitrogen gas from $4 \mathrm{~h}(\square)$ and the concomitant $\mathrm{DO}(\triangle)$, are shown. The arrows indicate the sampling points of C. glutamicum cells for transcriptional analysis. ' $\mathrm{N}_{2}$ ' in the figure indicates the start point of nitrogen supply instead of air.

After $4 \mathrm{~h}$ aerobic growth (DO 6.9 p.p.m), a $99.9 \%$ nitrogen gas supply was substituted for aeration (Fig. 4). DO was immediately reduced to 0.01 p.p.m. and the growth rate was drastically reduced. Cells after 5, 6 and $7 \mathrm{~h}$ (sampling points I, II and III in Fig. 4) of incubation were harvested from cultures supplied by air or nitrogen gas. Total RNAs were subsequently isolated from these samples and used for quantitative RT-PCR analysis.

The ratios of mRNA levels in the cells obtained by quantitative RT-PCR analysis under oxygen deprivation conditions after supplying nitrogen gas relative to those under aerobic conditions revealed that the gapA, $p g k$, tpi, $p p c, l d h A$ and $m d h$ genes were highly upregulated after 1,2 and $3 \mathrm{~h}$ of nitrogen gas supply (after 5,6 and $7 \mathrm{~h}$ of incubation) (Table 4). In particular, the $l d h A$ gene was more highly upregulated than the others, and we observed that L-lactate production was immediately started after nitrogen was supplied (data not shown). These data confirmed that these genes were upregulated by decreased oxygen tension.

\section{Time-course of gene expression under aerobic and oxygen deprivation conditions}

To facilitate the study of the regulation of the expression of gapA, $l d h A$ and $m d h$, three genes that are more than twofold upregulated under oxygen deprivation conditions, we integrated a monocopy of the lac $Z$ fusion on the chromosome, in which lac $Z$ expression was controlled by the transcriptional and translational regulatory signals of the gapA, ldhA and $m d h$ genes. The effect of aerobic and oxygen deprivation conditions on gapA, ldhA and $m d h$ expression was studied by measuring $\beta$-galactosidase levels in C. glutamicum that integrated each of these three lac $Z$ fusions.

When C. glutamicum that integrated the gapA-, ldhA-, and $m d h-l a c Z$ fusions was grown in A medium under aerobic conditions, the expression of the three genes was strongly induced, and there was a reduction of the DO tension at the onset of the stationary phase (Fig. 5a, c, e). High-level expression of the gapA-, ldhA- and $m d h-l a c Z$ fusions was maintained under oxygen deprivation conditions (Fig. 5b, d, f).

\section{Identification of the transcriptional start site}

To localize the gapA, $l d h A$ and $m d h$ promoters, the transcriptional start sites of these three genes were determined by primer extension using as primers at least three 20-mer oligonucleotides having different $5^{\prime}$-end positions (Supplementary Table S1). Reverse-transcription experiments were performed using the same batches of total RNA as those used for DNA microarray analyses and extracted from C. glutamicum cells under aerobic condi-

Table 4. Effect of oxygen tension on expression of the gapA gene cluster, and the $I d h A$ and $m d h$ genes

\begin{tabular}{|lccc|}
\hline \multirow{2}{*}{ Gene } & \multicolumn{3}{c|}{ Relative expression (nitrogen supply/aerobic) by quantitative RT-PCR } \\
\cline { 2 - 4 } & After $\mathbf{5} \mathbf{~ h}$ (sampling point I) $\dagger$ & After $\mathbf{6} \mathbf{~ h}$ (sampling point II) $\dagger$ & After 7 h (sampling point III) $\dagger$ \\
\hline$g a p A$ & $6.09( \pm 0.41)$ & $8.43( \pm 0.67)$ & $3.62( \pm 0.19)$ \\
$p g k$ & $3.87( \pm 0.03)$ & $6.18( \pm 0.18)$ & $3.05( \pm 0.08)$ \\
$t p i$ & $4.03( \pm 0.32)$ & $4.57( \pm 0.37)$ & $2.62( \pm 0.17)$ \\
$p p c$ & $2.32( \pm 0.32)$ & $2.75( \pm 0.30)$ & $1.74( \pm 0.06)$ \\
$l d h A$ & $24.93( \pm 2.04)$ & $24.46( \pm 2.13)$ & $6.64( \pm 0.61)$ \\
$m d h$ & $9.41( \pm 0.71)$ & $8.85( \pm 0.50)$ & $3.61( \pm 0.44)$ \\
\hline
\end{tabular}

*The values are mean \pm SD for three independent determinations.

$\dagger$ The sampling points in Fig. 4. 
(a)

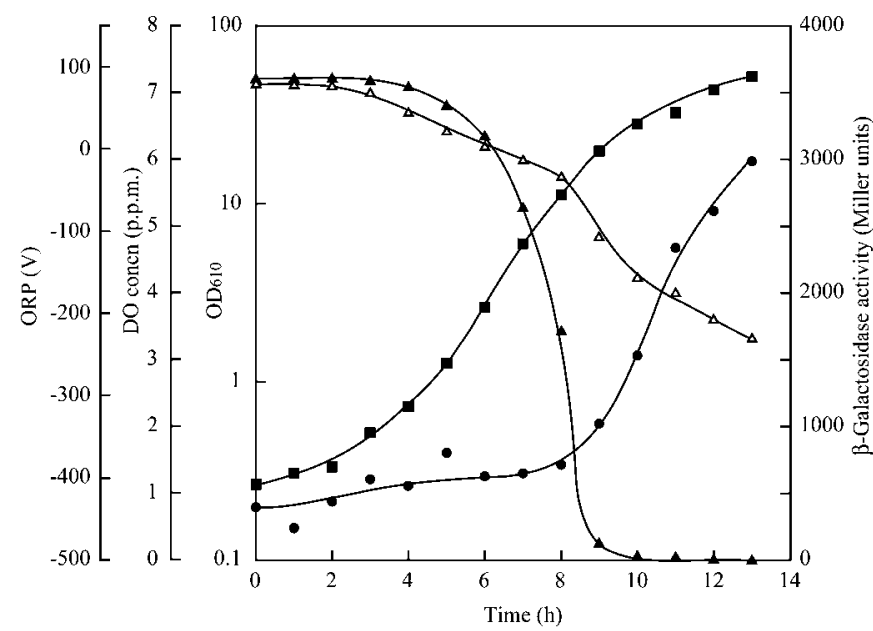

(c)

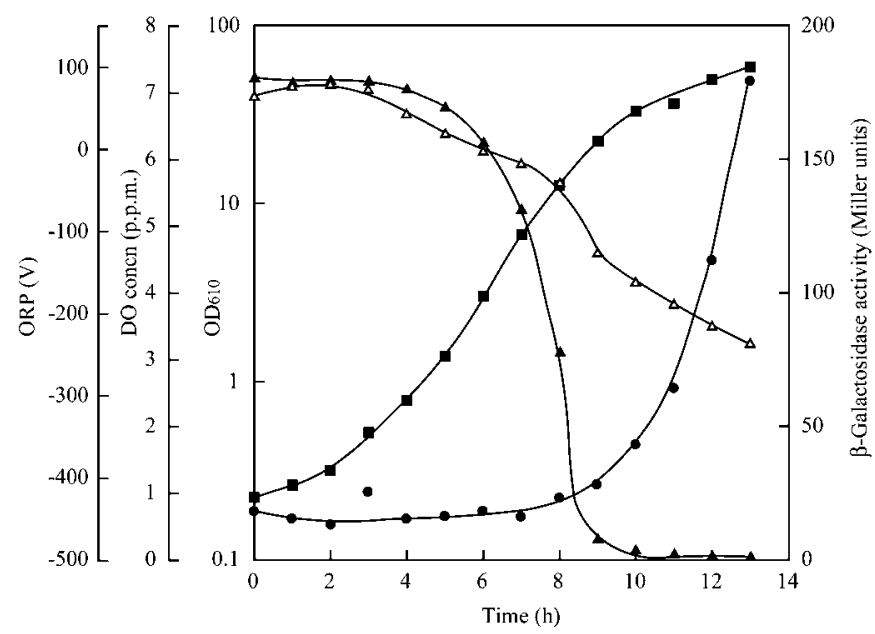

(e)

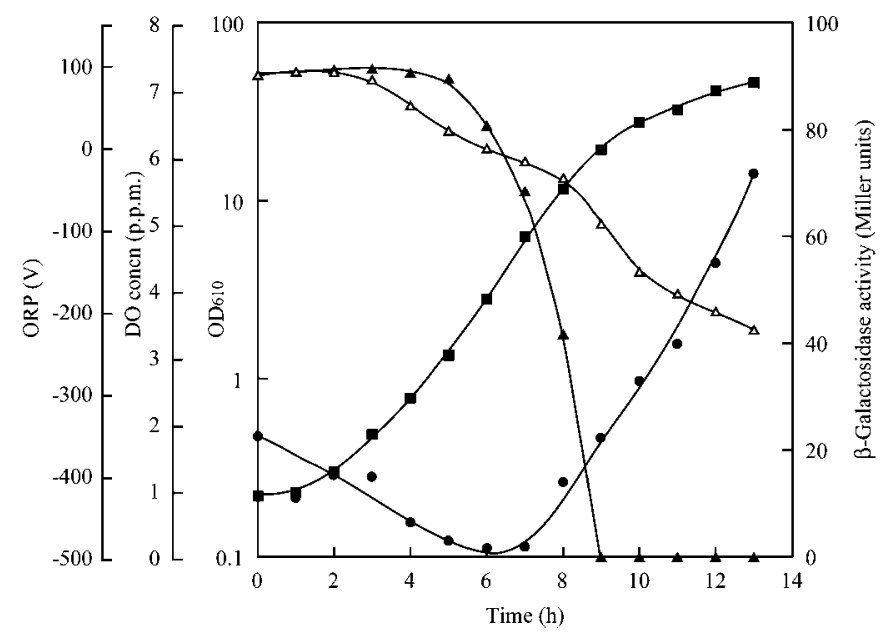

(b)

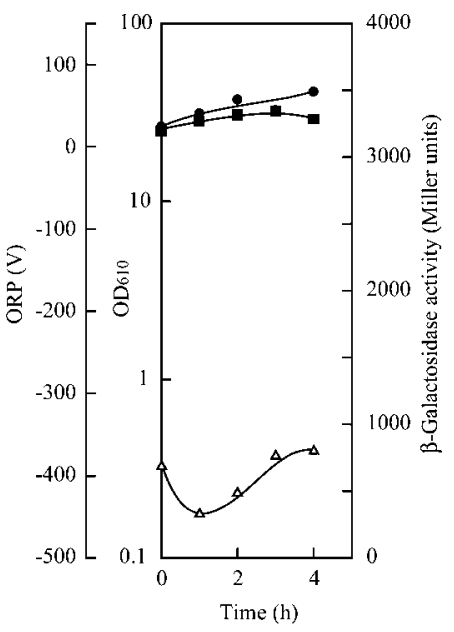

(d)

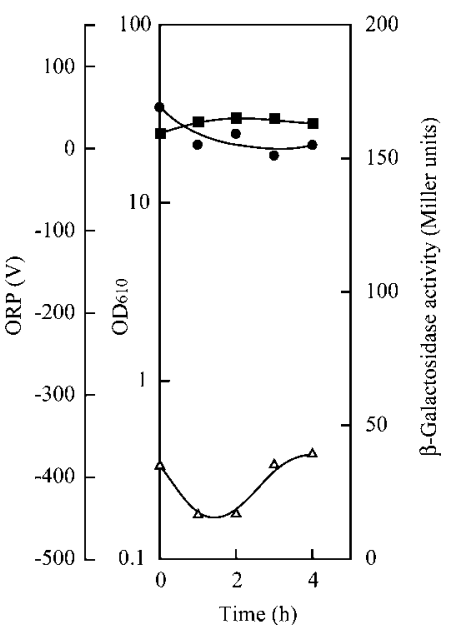

(f)

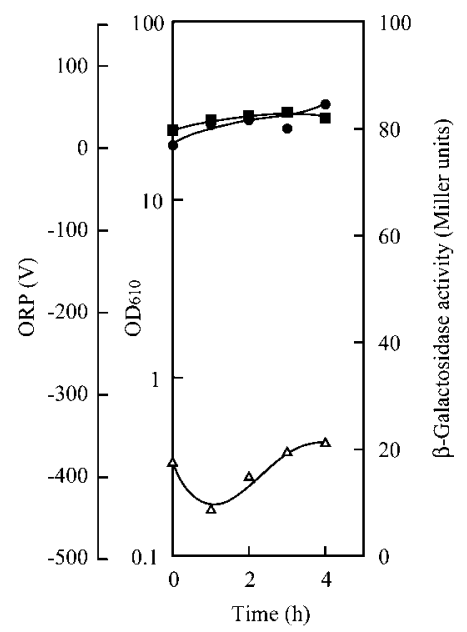

Fig. 5. Expression profiles of gapA-, $I d h A-$ and $m d h-l a c Z$ fusion genes during aerobic cultivation and oxygen deprived conditions. Cell density $(\boldsymbol{\square}), \mathrm{DO}(\boldsymbol{\Lambda}), \mathrm{ORP}(\triangle)$ and $\beta$-galactosidase activity $(\boldsymbol{\bullet})$ are shown during aerobic cultivation (a, c, e) and oxygen deprived conditions ( $\mathrm{b}, \mathrm{d}, \mathrm{f}$ ) of $\mathrm{C}$. glutamicum $\mathrm{R}$ integrating a gapA-lacZ fusion $(\mathrm{a}, \mathrm{b})$, a /dhA-lacZ fusion (c, d) and a $m d h-l a c Z$ fusion $(e, f)$ on the chromosome. 

(a)

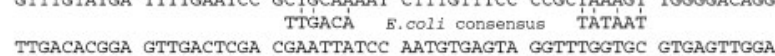
AAATTTCGCC ATACTCGCCC TTGGGTTCTG TCAGCTCAAG AATTCTTGAG TGACCGATGC

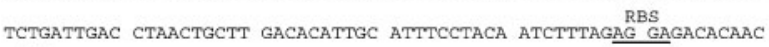
$+185$ ATGACCATTC GTGTTGGTAT TAACGGATTT GGAAGTATCG GACGTAACTT CTTCCGCGCA $\begin{array}{lllllllllllllllllllllll}M & T & I & R & V & G & I & N & G & F & G & R & I & G & R & N & F & F & R & A\end{array}$

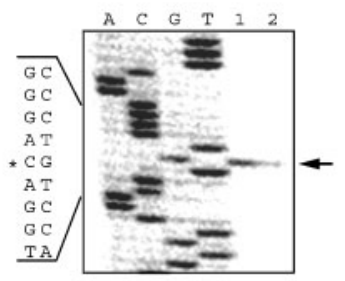

(b)

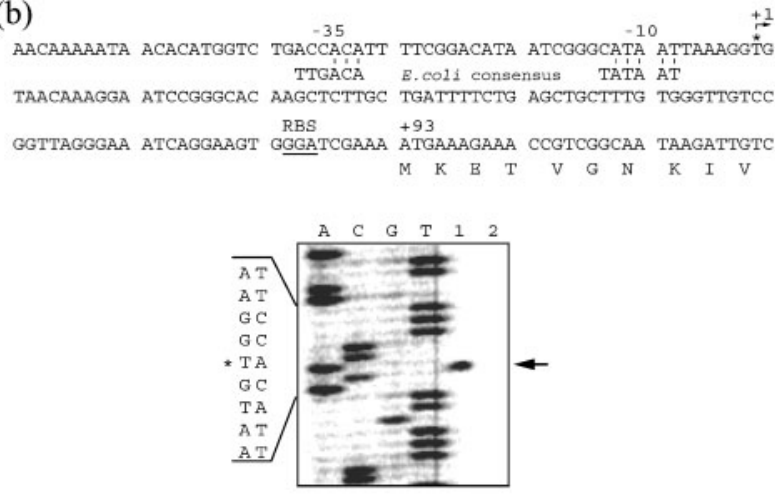

(c)
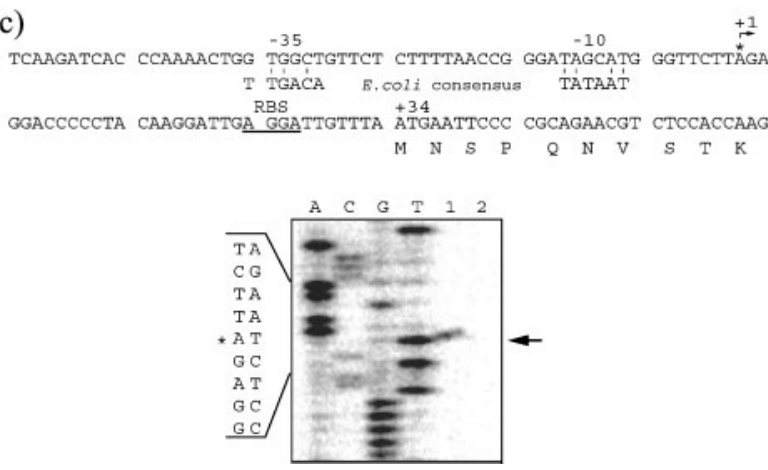

tions (at point I in Fig. 1a) and oxygen deprivation conditions (at point II in Fig. 1b).

Primer-extension analyses of the gapA, $l d h A$ and $m d h$ genes revealed that, in all cases, a single major extension product was generated both under oxygen deprivation conditions (Fig. 6, lane 1) and aerobic conditions (Fig. 6, lane 2) with all three/four primers (Supplementary Table S1), corresponding to a $5^{\prime}$-end located 185,93 or 34 bp upstream of the $g a p A, l d h A$ or $m d h$ translation initiation codon, respectively. The results obtained with primer 51 for the gapA gene (Fig. 6a), primer 55 for the ldhA gene (Fig. 6b) and primer 58 for the $m d h$ gene (Fig. 6c) are shown. The transcriptional signals of the gapA, ldhA and $m d h$ genes
Fig. 6. Primer-extension analyses of the gap $A, \operatorname{ld} h A$ and $m d h$ genes under oxygen deprivation and aerobic conditions. Sequence features upstream and downstream of the start point of transcription (upper figure) and sequencing gel analyses of primer extension (lower figure) are shown for the $\operatorname{gap} A(\mathrm{a}), \operatorname{ld} h A(\mathrm{~b})$ and $m d h$ (c) genes. For each sequence upstream of the start codon, a bent arrow marked +1 shows the start point of the transcript. Regions at distances canonical for promoters ( -35 and -10 relative to the initiation codon) are indicated. The E. coli $\sigma^{70}$ recognition consensus is represented underneath. Bases conserved between the two sequences are indicated by vertical bars. The putative ribosome binding site (RBS) is underlined. The first base of the start codon is indicated at position +185 for the gap $A$ gene, +93 for the $I d h A$ gene and +34 for the $m d h$ gene, and the single-letter amino acid code for the amino terminus of the protein is presented below the sequence. For each sequencing gel analysed by primer extension, the products of high-resolution electrophoresis of 5'-labelled cDNA are shown aligned with a sequencing ladder generated from DNA from the same region, using the same primer. Dideoxy sequencing marker lanes $A, C, T$ and $G$ are indicated, and cDNA synthesis of the RNA samples is shown in lane 1 (under oxygen deprivation conditions) and lane 2 (under aerobic conditions). The migration position of the single primer extension product is indicated with an arrow. A portion of the DNA sequence is shown on the left, and the asterisk indicates the putative transcriptional start site.

under oxygen deprivation conditions were much stronger than those of the same genes under aerobic conditions, as observed in DNA microarray (Table 2, Fig. 3) and lacZ fusion (Fig. 5) experiments. Upstream of the transcriptional start sites of the $g a p A, l d h A$ and $m d h$ genes, putative -10 and -35 promoter sequences, which share some similarities with the E. coli $\sigma^{70}$ promoter consensus (Hawley \& McClure, 1983), were observed. The transcriptional start site of the gapA gene in C. glutamicum R under oxygen deprivation conditions, as studied in this report, was identical to that in C. glutamicum ATCC 13032 grown under aerobic conditions and reported elsewhere (Schwinde et al., 1993).

\section{DISCUSSION}

The adaptive response to oxygen deprivation conditions exhibited by $C$. glutamicum is similar to those previously observed in virtually every organism submitted to hypoxia. The genes coding for the main enzymes of the glycolytic pathway are upregulated at the transcriptional level, including gapA, $p g k$, tpi and $p p c$, which form a gene cluster in the $C$. glutamicum R genome (Yukawa et al., 2007). However, the respective contributions of each of these enzymes to the increase of the glycolytic flux in C. glutamicum under oxygen deprivation conditions remain unclear.

Studies with a gapA-lacZ fusion suggest that the gapA gene is strongly induced at the onset of the stationary phase under aerobic growth conditions. Moreover, increased 
expression of the gapA gene was sustained under oxygen deprivation conditions. The maintenance of the upregulation of gapA gene expression under oxygen deprivation conditions was consistently observed with three different methods: lacZ fusion, DNA microarray and quantitative RT-PCR.

Notwithstanding this observation, GAPDH activity has been demonstrated not to exert a significant control over the glycolytic flux in Lactococcus lactis, since the wild-type levels of this enzyme observed in this organism represent a three- to fourfold excess (Solem et al., 2003). In addition, moderate overexpression of phosphofructokinase $(p f k)$ and pyruvate kinase ( $p y k)$ has been shown not to dramatically modify flux ratios in E. coli (Sauer et al., 1999). Perhaps the physiological significance of the latter observed transcriptional increases is limited, as recent studies in E. coli have demonstrated that, in this organism, the glycolytic flux is chiefly controlled by the intracellular demand for ATP, rather than by the overexpression of the enzymes of the pathway (Koebmann et al., 2002a, b). On the other hand, PEPC, encoded by $p p c$, which belongs to the same gene cluster as gapA, is threefold upregulated in C. glutamicum $\mathrm{R}$ under oxygen deprivation conditions. Under these conditions, the OAA pool is replenished via conversion of phosphoenolpyruvate catalysed by PEPC, rather than via conversion of pyruvate through the action of the enzyme PC; this observation raises the question whether the pyruvate kinase step could be rate limiting (Inui et al., 2004a, b), due either to redox imbalances or to insufficient pyruvate kinase activity. Pyruvate kinase has been shown elsewhere to be a controlling node of the corynebacterial glycolytic pathway, as it is subject to allosteric activation by AMP (Jetten et al., 1994). Similarly, in E. coli under anaerobic conditions, the activity of the TCA cycle is reduced and anaplerosis via PEPC action predominantly generates OAA that feeds the reductive arm of the TCA cycle (Sauer et al., 1999). PEPC overexpression enables succinate production by $C$. glutamicum under oxygen deprivation conditions, involving the subsequent exclusive action of $\mathrm{MDH}$, as demonstrated by the inability of $C$. glutamicum $\mathrm{MDH}$ mutants to produce succinate. $C$. glutamicum possesses two types of L-malate dehydrogenase, $\mathrm{MDH}$, a cytoplasmic, NAD-dependent malate dehydrogenase, and a highly active membrane-associated malate: quinone oxidoreductase (MQO) (Molenaar et al., 1998). Under aerobic conditions, MQO, not $\mathrm{MDH}$, is responsible for the net flux from malate to OAA within the TCA cycle (Eikmanns, 2005), and an MQO-deficient mutant is unable to grow on minimal medium, whereas an $\mathrm{MDH}$-negative mutant has no obvious phenotype (Molenaar et al., 2000). In addition, this enzyme may contribute to the backflux from OAA to fumarate, as detected by NMR flux quantification (Eikmanns, 2005). We therefore inferred that under oxygen deprivation, $m d h$ gene expression is induced and $\mathrm{MDH}$ mainly functions for the backflux from OAA to fumarate with subsequent succinate production. The physiological value to the C. glutamicum cell under oxygen deprivation conditions of upregulating both $p p c$ and $m d h$, which serve as key nodes in the metabolic network, is perhaps to commit the carbon chains to the reductive arm of the TCA cycle. A similar response is observed at the level of the expression of $l d h A$, which is present in a single copy in the C. glutamicum genome (Inui et al., 2004b). The NAD-dependent LDH was 8.6-fold upregulated under oxygen deprivation conditions, perhaps to enable the cell to more efficiently regenerate its $\mathrm{NAD}^{+}$ pool, and thus compensate, among other things, for the down-regulation of the oxidative arm of the TCA cycle and the cessation of energy-generating respiration.

Most genes in the oxidative arm of the TCA cycle, namely gltA, acn, icd, sucA, sucB, sucC and sucD, are downregulated in C. glutamicum under oxygen deprivation conditions, which is consistent with the observation made in other organisms that under anaerobic conditions the primary function of the TCA cycle is to replenish biosynthetic precursors and not to generate energy. Likewise, the citrate synthase encoded by the gltA gene is down-regulated in oxygen-deprived C. glutamicum, similar to what is observed in B. subtilis (Nakano et al., 1998). The physiological impact of this phenomenon remains to be elucidated.

The ubiquitous changes occasioned particularly by a sharp decrease in oxygen tension are apparent at the level of other energy components of the corynebacterial cell. For example, it is worth noting that transcription of the corynebacterial $\mathrm{H}^{+}$-ATPase operon under oxygen deprivation conditions is sharply decreased to one-quarter to onehalf of its level under aerobic conditions. This is in sharp contrast to what is observed in the facultative anaerobe $E$. coli, in which anaerobic cell growth on glucose minimal salts medium leads to $\mathrm{H}^{+}$-ATPase expression that is $30 \%$ higher than that attained under aerobic growth (Kasimoglu et al., 1996). The physiological function of the ATPase complex is to generate ATP from ADP and $\mathrm{P}_{\mathrm{i}}$ by electron transport-linked phosphorylation under aerobic conditions. Under non-respiratory conditions, the ATPase complex hydrolyses ATP to maintain an electrochemical gradient across the bacterial membrane. E. coli ATPasedeficient mutants exhibit increased flow through the TCA and glycolytic pathways (Jensen \& Michelsen, 1992; Jensen et al., 1995), with ATP being generated by an increased rate of glucose consumption and acetate generation. The increased flow through glycolysis and the TCA cycle results in an increased generation of $\mathrm{NADH}$, which is compensated by an increased respiration rate without the generation of energy. Similarly, B. subtilis mutants grown aerobically consume twice the amount of glucose for the same increase in biomass, and exhibit increased synthesis of terminal oxidases, including ubiquinol oxidase and $a$ type haem, leading to an increased respiration rate, albeit also uncoupled from the generation of ATP (Santana et al., 1994). $\mathrm{H}^{+}$-ATPase mutant C. glutamicum also exhibits an increased respiration rate, an increased glucose consumption rate per cell, increased glycolysis, and decreased 2- 
oxoglutarate production, suggesting a decreased flow through the oxidative arm of the TCA cycle, increased production and intracellular accumulation of pyruvate, and increased lactate production (Sekine et al., 2001). Combined, these various observations suggest that, like $E$. coli and B. subtilis, C. glutamicum adjusts its metabolism in the absence of oxidative phosphorylation to maintain its energy level as high as possible, through mechanisms that, overall, have been highly conserved under different selective forces during two billion years of evolution since the divergence of Gram-negative and Gram-positive bacteria.

In C. glutamicum, and again similar to what is observed in B. subtilis (Ye et al., 2000) and E. coli (Kang et al., 2005), numerous other genes are induced or repressed with changes in environmental conditions such as oxygen tension. Among the genes observed to be highly inducible in the last two species, beyond those genes involved in anaerobic respiration, carbon metabolism and electron transport, iron uptake, stress response and several hypothetical genes are also upregulated. In B. subtilis and E. coli, the major regulator of the physiological switch between aerobic and anaerobic growth conditions is the DNA binding protein FNR (Gunsalus \& Park, 1994; Kang et al., 2005; Pao et al., 1994; Ye et al., 2000). For example, in E. coli, 297 genes constituting 184 different operons are regulated by FNR and/or oxygen levels (Kang et al., 2005). However, other global transcriptional regulators have been shown to play important roles, such as ArcA, which impacts redox regulation, and whose knockout increases the activity of the TCA cycle by $60 \%$ in E. coli (Perrenoud \& Sauer, 2005). Similarly, down-regulation of the transcription of citrate synthase and aconitase in B. subtilis under anaerobiosis is driven by a mechanism that is different from those involving $\mathrm{CcpA}, \mathrm{CcpB}, \mathrm{FNR}$ and ResDE (Nakano et al., 1998).

The overall physiological consequence of the observed increased transcription in corynebacteria under oxygen deprivation process conditions is an increased rate of carbon-source consumption, and presumably an increased flow of carbon through the glycolytic pathway and the reductive arm of the TCA cycle, accompanied by a concomitant increase in organic acid production. The numerous transcriptional changes observed under varying environmental conditions suggest the presence in $C$. glutamicum, as in other organisms, of one or more pleiotropic transcriptional regulators that are activated when cells are subjected to oxygen deprivation conditions and perhaps mediated by sensing-effector cascades. In addition to its fundamental scientific interest, the understanding of the molecular basis of the biological response of C. glutamicum to oxygen deprivation conditions will help design more efficient processes for industrial biotechnology.

\section{ACKNOWLEDGEMENTS}

We thank S. Murakami for technical support. We thank Roy H. Doi (University of California at Davis) and Crispinus A. Omumasaba
(RITE) for critical reading of the manuscript. This work was financially supported in part by the New Energy and Industrial Technology Development Organization (NEDO), Japan.

\section{REFERENCES}

Billman-Jacobe, H., Wang, L., Kortt, A., Stewart, D. \& Radford, A. (1995). Expression and secretion of heterologous proteases by Corynebacterium glutamicum. Appl Environ Microbiol 61, 1610-1613.

Bunch, P. K., Mat-Jan, F., Lee, N. \& Clark, D. P. (1997). The $l d h A$ gene encoding the fermentative lactate dehydrogenase of Escherichia coli. Microbiology 143, 187-195.

Eggeling, L. \& Sahm, H. (1999). Amino acid production: principles of metabolic engineering. In Metabolic Engineering, pp. 153-176. Edited by S. Y. Lee \& E. T. Papoutsakis. New York: Marcel Dekker.

Eikmanns, B. J. (1992). Identification, sequence analysis, and expression of a Corynebacterium glutamicum gene cluster encoding the three glycolytic enzymes glyceraldehyde-3-phosphate dehydrogenase, 3-phosphoglycerate kinase, and triosephosphate isomerase. $J$ Bacteriol 174, 6076-6086.

Eikmanns, B. (2005). Central metabolism: tricarboxylic acid cycle and anaplerotic reactions. In Handbook of Corynebacterium glutamicum, pp. 241-276. Edited by L. Eggeling \& M. Bott. Boca Raton, FL: CRC Press.

Emmerling, M., Bailey, J. E. \& Sauer, U. (2000). Altered regulation of pyruvate kinase or co-overexpression of phosphofructokinase increases glycolytic fluxes in resting Escherichia coli. Biotechnol Bioeng 67, 623-627.

Gottschalk, G. (1985). Bacterial Metabolism, 2nd edn. New York: Springer.

Gunsalus, R. P. \& Park, S. J. (1994). Aerobic-anaerobic gene regulation in Escherichia coli: control by the ArcAB and Fnr regulons. Res Microbiol 145, 437-450.

Hawley, D. K. \& McClure, W. R. (1983). Compilation and analysis of Escherichia coli promoter DNA sequences. Nucleic Acids Res 11, 22372255.

Hermann, T. (2003). Industrial production of amino acids by coryneform bacteria. J Biotechnol 104, 155-172.

Inui, M., Dumay, V., Zahn, K., Yamagata, H. \& Yukawa, H. (1997). Structural and functional analysis of the phosphoenolpyruvate carboxylase gene from the purple nonsulfur bacterium Rhodopseudomonas palustris no. 7. J Bacteriol 179, 4942-4945.

Inui, M., Terasawa, M. \& Yukawa, H. (1999a). L-Isoleucine. In Encyclopedia of Bioprocess Technology: Fermentation, Biocatalysis, and Bioseparation, pp. 1498-1503. Edited by M. C. Flickinger \& S. W. Drew. New York: Wiley.

Inui, M., Nakata, K., Roh, J. H., Zahn, K. \& Yukawa, H. (1999b). Molecular and functional characterization of the Rhodopseudomonas palustris no. 7 phosphoenolpyruvate carboxykinase gene. J Bacteriol 181, 2689-2696.

Inui, M., Kawaguchi, H., Murakami, S., Vertès, A. A. \& Yukawa, H. (2004a). Metabolic engineering of Corynebacterium glutamicum for fuel ethanol production under oxygen deprivation conditions. $J \mathrm{Mol}$ Microbiol Biotechnol 8, 243-254.

Inui, M., Murakami, S., Okino, S., Kawaguchi, H., Vertès, A. A. \& Yukawa, H. (2004b). Metabolic analysis of Corynebacterium glutamicum during lactate and succinate productions under oxygen deprivation conditions. J Mol Microbiol Biotechnol 7, 182-196.

Jensen, P. R. \& Michelsen, O. (1992). Carbon and energy metabolism of atp mutants of Escherichia coli. J Bacteriol 174, 7635-7641. 
Jensen, P. R., Michelsen, O. \& Westerhoff, H. V. (1995). Experimental determination of control by the $\mathrm{H}^{+}$-ATPase in Escherichia coli. $J$ Bioenerg Biomembr 27, 543-554.

Jetten, M. S., Gubler, M. E., Lee, S. H. \& Sinskey, A. J. (1994). Structural and functional analysis of pyruvate kinase from Corynebacterium glutamicum. Appl Environ Microbiol 60, 2501-2507.

Kang, Y., Weber, K. D., Qiu, Y., Kiley, P. J. \& Blattner, F. R. (2005). Genome-wide expression analysis indicates that FNR of Escherichia coli $\mathrm{K}-12$ regulates a large number of genes of unknown function. $J$ Bacteriol 187, 1135-1160.

Kasimoglu, E., Park, S. J., Malek, J., Tseng, C. P. \& Gunsalus, R. P. (1996). Transcriptional regulation of the proton-translocating ATPase (atpIBEFHAGDC) operon of Escherichia coli: control by cell growth rate. J Bacteriol 178, 5563-5567.

Kelle, R., Hermann, T. \& Bathe, B. (2005). L-Lysine production. In Handbook of Corynebacterium glutamicum, pp. 465-488. Edited by L. Eggeling \& M. Bott. Boca Raton, FL: CRC Press.

Koebmann, B. J., Westerhoff, H. V., Snoep, J. L., Nilsson, D. \& Jensen, P. R. (2002a). The glycolytic flux in Escherichia coli is controlled by the demand for ATP. J Bacteriol 184, 3909-3916.

Koebmann, B. J., Westerhoff, H. V., Snoep, J. L., Solem, C., Pedersen, M. B., Nilsson, D., Michelsen, O. \& Jensen, P. R. (2002b). The extent to which ATP demand controls the glycolytic flux depends strongly on the organism and conditions for growth. Mol Biol Rep 29, 41-45.

Kumagai, H. (2000). Microbial production of amino acids in Japan. Adv Biochem Eng Biotechnol 69, 71-85.

Molenaar, D., van der Rest, M. E. \& Petrovic, S. (1998). Biochemical and genetic characterization of the membrane-associated malate dehydrogenase (acceptor) from Corynebacterium glutamicum. Eur J Biochem 254, 395-403.

Molenaar, D., van der Rest, M. E., Drysch, A. \& Yucel, R. (2000). Functions of the membrane-associated and cytoplasmic malate dehydrogenases in the citric acid cycle of Corynebacterium glutamicum. J Bacteriol 182, 6884-6891.

Murakami, S., Nakata, K., Okino, S., Ikenaga, Y., Inui, M. \& Yukawa, H. (2005). Coryneform bacterium transformant and process for producing dicarboxylic acid using the same. PCT patent application, WO 2005/010182 A1.

Nakano, M. M., Zuber, P. \& Sonenshein, A. L. (1998). Anaerobic regulation of Bacillus subtilis Krebs cycle genes. J Bacteriol 180, 33043311.

Okino, S., Inui, M. \& Yukawa, H. (2005). Production of organic acids by Corynebacterium glutamicum under oxygen deprivation. Appl Microbiol Biotechnol 68, 475-480.

Omumasaba, C. A., Okai, N., Inui, M. \& Yukawa, H. (2004). Corynebacterium glutamicum glyceraldehyde-3-phosphate dehydrogenase isoforms with opposite, ATP-dependent regulation. $J \mathrm{Mol}$ Microbiol Biotechnol 8, 91-103.

Pao, G. M., Tam, R., Lipschitz, L. S. \& Saier, M. H., Jr (1994). Response regulators: structure, function and evolution. Res Microbiol 145, 356362.

Perrenoud, A. \& Sauer, U. (2005). Impact of global transcriptional regulation by ArcA, ArcB, Cra, Crp, Cya, Fnr, and Mlc on glucose catabolism in Escherichia coli. J Bacteriol 187, 3171-3179.
Peters-Wendisch, P. G., Schiel, B., Wendisch, V. F., Katsoulidis, E., Mockel, B., Sahm, H. \& Eikmanns, B. J. (2001). Pyruvate carboxylase is a major bottleneck for glutamate and lysine production by Corynebacterium glutamicum. J Mol Microbiol Biotechnol 3, 295-300.

Salim, K., Haedens, V., Content, J., Leblon, G. \& Huygen, K. (1997). Heterologous expression of the Mycobacterium tuberculosis gene encoding antigen $85 \mathrm{~A}$ in Corynebacterium glutamicum. Appl Environ Microbiol 63, 4392-4400.

Sambrook, J., Fritsch, E. F. \& Maniatis, T. (1989). Molecular Cloning: a Laboratory Manual, 2nd edn. Cold Spring Harbor, NY: Cold Spring Harbor Laboratory.

Santana, M., lonescu, M. S., Vertès, A., Longin, R., Kunst, F., Danchin, A. \& Glaser, P. (1994). Bacillus subtilis $\mathrm{F}_{0} \mathrm{~F}_{1}$ ATPase: DNA sequence of the atp operon and characterization of atp mutants. $J$ Bacteriol 176, 6802-6811.

Sauer, U., Lasko, D. R., Fiaux, J., Hochuli, M., Glaser, R., Szyperski, T., Wuthrich, K. \& Bailey, J. E. (1999). Metabolic flux ratio analysis of genetic and environmental modulations of Escherichia coli central carbon metabolism. J Bacteriol 181, 6679-6688.

Schwinde, J. W., Thum-Schmitz, N., Eikmanns, B. J. \& Sahm, H. (1993). Transcriptional analysis of the gap-pgk-tpi-ppc gene cluster of Corynebacterium glutamicum. J Bacteriol 175, 3905-3908.

Sekine, H., Shimada, T., Hayashi, C., Ishiguro, A., Tomita, F. \& Yokota, A. (2001). $\mathrm{H}^{+}$-ATPase defect in Corynebacterium glutamicum abolishes glutamic acid production with enhancement of glucose consumption rate. Appl Microbiol Biotechnol 57, 534-540.

Solem, C., Koebmann, B. J. \& Jensen, P. R. (2003). Glyceraldehyde-3phosphate dehydrogenase has no control over glycolytic flux in Lactococcus lactis MG1363. J Bacteriol 185, 1564-1571.

Sridhar, J., Eiteman, M. A. \& Wiegel, J. W. (2000). Elucidation of enzymes in fermentation pathways used by Clostridium thermosuccinogenes growing on inulin. Appl Environ Microbiol 66, 246-251.

Suzuki, N., Okayama, S., Nonaka, H., Tsuge, Y., Inui, M. \& Yukawa, H. (2005). Large-scale engineering of the Corynebacterium glutamicum genome. Appl Environ Microbiol 71, 3369-3372.

Vertès, A. A., Inui, M., Kobayashi, M., Kurusu, Y. \& Yukawa, H. (1993a). Presence of $m r r-$ and $m c r$-like restriction systems in coryneform bacteria. Res Microbiol 144, 181-185.

Vertès, A. A., Hatakeyama, K., Inui, M., Kobayashi, M., Kurusu, Y. \& Yukawa, H. (1993b). Replacement recombination in coryneform bacteria: high efficiency integration requirement for non-methylated plasmid DNA. Biosci Biotechnol Biochem 57, 2036-2038.

Vertès, A. A., Inui, M. \& Yukawa, H. (2005). Manipulating corynebacteria, from individual genes to chromosomes. Appl Environ Microbiol 71, 7633-7642.

Ye, R. W., Tao, W., Bedzyk, L., Young, T., Chen, M. \& Li, L. (2000). Global gene expression profiles of Bacillus subtilis grown under anaerobic conditions. J Bacteriol 182, 4458-4465.

Yukawa, H., Omumasaba, C. A., Nonaka, H., Kós, P., Okai, N., Suzuki, N., Suda, M., Tsuge, Y., Watanabe, J. \& other authors (2007). Comparative analysis of the Corynebacterium glutamicum group and complete genome sequence of strain R. Microbiology 153, 1042-1058.

Edited by: C. W. Chen 